\title{
Pedia There Is No Music Industry
}

\author{
Jonathan Sterne ${ }^{1}$ \\ McGill University \\ jonathan.sterne [AT] mcgill.ca
}

\begin{abstract}
:
The locution "music industry" still too often refers to a single subset of profit-making practices in music: record labels and the activities around them. Media scholars are partly to blame, as they continue to define record labels, and especially labels that are part of conglomerates, in this way. Yet this notion of the production and sale of recordings as the basis of "the music industry" is hardly a part that represents the whole. Drawing on the work of Christopher Small and others who have decentered the musical text as the basis of music criticism, I argue that media industries scholars must do the same, opening up our inquiries to a wide range of music industries; that is, industries whose activities directly affect the performance, production, circulation, consumption, recirculation, appropriation, and enjoyment of music today. Opening the term up in this way will allow us to develop more robust and coherent social accounts of music as a media practice, and provide a stronger empirical basis for criticizing current institutional arrangements and proposing new, more just and convivial alternatives.
\end{abstract}

Keywords: Music, Digitalization, Political Economy, Cultural Studies

The term "music industry" remains in wide circulation among academics, as well as in common journalistic discourse. We can find it in research on political economy, scholarship on file sharing, studies of musicians, and aesthetic analyses of recording practices. The term generally refers to the sale and purchase of recordings, the bundles of rights that go with them, and the livelihoods of people involved in that economy, ranging from musicians and fans to accountants, artists and repertoire (A\&R) people, street teams, engineers, producers, lawyers, and record company executives, among others. In this conceptualization, "the music industry" is broadly concerned with the monetization of music recordings. When people write about a music industry "in crisis" or "the future of the music industry," they are generally referring to the monetizationof-recordings construct.

As I will argue, this is an incredibly limited way to understand how media industries and music interact. But first, we should understand why this nomenclature persists in media industries scholarship. There are at least two key reasons. First, to reduce the music industries to those involved with the monetization of recordings in fact adopts a 
public relations tactic used by groups such as the Recording Industry Association of America, in which companies that sell recordings claim to speak for musicians and by extension, music itself as a part of our cultural life. It's not that scholars are on the PR payrolls of companies but rather that we have been insufficiently attentive to the construction of our objects of research. We have accepted the "pregiven" in Pierre Bourdieu's words, rather than beginning with constructing our own objects. ${ }^{2}$

The "music industry" locution crystallizes a particular historical formation of music production, circulation, and consumption as ideal-typical. Some components of this formulation are worth considering as they have come under significant criticism by scholars in a number of fields:

1. An idea of "music industry" generally assumes that recordings are made up of "works," whether songs, movements, or pieces. These works have an author, are original, can be copyrighted, and can be protected by (theoretically) limited-term monopolies on circulation afforded by copyright and international trade agreements.

2. In the above model, successful musicianship is tied to successful commercialization of recordings; that is, making a living off the rights to one's original works. Of course, this immediately begs the question of what counts as originality, a matter settled in copyright law but not settled in aesthetics. We can copyright melodies, lyrics, and some timbres, but not rhythms. Therefore, only some kinds of originality count. Regardless of the genre to which this model is applied, it requires the notion of an "artist" who produces the original work, and can either hold copyright for that "work" or sell it to a holding company (i.e., a label) that will collect rent. Implied in this economic relationship is a notion of originality as the highest aesthetic ideal. Presumably that originality is a product of creativity, which is a quality that resides in the artist. Moreover, it privileges "the work" as the most important aspect of musical activity, as the work is the thing that is given monetary value and is the basis of exchange.

For several decades now, these ideas have been under criticism in a number of fields. Media industries scholars may be most familiar with the scholarship on the complexity of copyright, from Siva Vaidhyanathan's critique of "property talk" to Kembrew McLeod's critiques of the ideas of ownership of culture. ${ }^{3}$ But an equally vital tradition exists in interdisciplinary music studies. Ethnomusicologists have attacked the workbased notion of music since at least Alan P. Merriam's 1964 Anthropology of Music. Writers like LeRoi Jones and Charles Keil, based on their analysis of African-American blues and jazz traditions, argue that musical meaning is inhered in collective activity and participation, not in a static text. Christopher Small's work is particularly important here. His 1977 text Music-Society-Education built on Ivan Illich's philosophy of technology to argue for a diffusion of musical education and against the idea that musical talent inheres in only some people and not others. ${ }^{4}$

But it is Small's later book, Musicking (1998), which provides a particularly useful jumping-off point for media industries scholars interested in music. Small builds his argument around a simple turn: "Music" should be understood as a verb instead of a noun. As he defines it:

To music is to take part, in any capacity, in a musical performance, whether by performing, by listening, by rehearsing or practicing, by 
providing material for performance (what is called composing), or by dancing. We might at times even extend its meaning to what the person is doing who takes the tickets at the door or the hefty men who shift the piano and the drums or the roadies who set up the instruments and carry out the sound checks or the cleaners who clean up after everyone else has gone. They, too, are all contributing to the nature of the event that is a musical performance. ${ }^{5}$

Small's point is essential: We miss a lot by focusing everything around the musiciansaudiences-recordings nexus and we miss even more when we limit our understanding of music as a social practice to the objects sold as "music" in its wake. Louise Meintjes's classic ethnography of a South African recording studio also illustrates this way of thinking: behind the "making of a record" lie many varied social relations that crisscross race, gender, nation, and economy. ${ }^{6}$

Today we can extend Small's argument in dozens of directions. To begin with, defining "music" as a commodity is extremely limited considering the range of commodities sold through, with, or around music, ranging from musical instruments, to hardware and software, to smartphones, to speakers and room architectures. To understand music as an industrial phenomenon goes far beyond those industries directly involved with the sale of recordings. For instance, we need to consider the music instrument industries (manufacturing, sales, marketing, development, retail, etc.), which have consistently grown during the same years that sales in the so-called "music industry" have been in decline. We need to consider rights-based work, such as soundtracks and music supervision, so central to the sound of modern television, film, and video games. We need to consider sound design in high-end automobiles, as well as sound insulation in trendy condo developments in gentrifying mixed-use urban districts. We need to consider the vast consumer electronics, computing, and bandwidth industries, not to mention companies like YouTube, which have used recorded music to market their products. Even though they don't sell music, they sell musical experiences. People pay their monthly internet bills, buy their smartphones, and visit internet sites to play music and have musical experiences.

Thus, as with its cultural life, music's economic life extends far beyond remediations of live performance. It touches upon various manufacturing industries; computer hardware and software; media conglomerates' synergy proposals and other media holdings; materials extraction, mining, refinement, and recycling; containerized shipping industries; higher education and vernacular forms of music education; real estate; the postal system; fashion; and countless other industries.

In his classic study of musical instrument industries, Paul Théberge adopted "multisectorial innovation," a term from agricultural economics, to describe what happened to electronic musicians in the 1980s and 1990s. ${ }^{7}$ As they used devices with microchips, memory, and software, musicians and the music industry became more dependent on economic cycles in other industrial sectors - in this case, computers. The cycle toward obsolescence of musical instruments accelerated greatly during this time. These same factors also spawned a number of interesting retro and vintage markets due to the association of certain instruments with certain genres, as well as platforms for 
international second-hand trade, like craigslist or eBay (though to be clear, the vintage market in musical instruments has a considerably longer history than the internet). ${ }^{8}$

While Théberge's point is specific to instruments, it is generalizable to pretty much all industries involved with music today. This is most obvious in cases of hardware and software that orbit around the purchase and sale of recordings, as Jeremy Morris has documented. ${ }^{9}$ But so far the scholarship has tended toward considering music as a subset of digital media industries. Scholars interested in the proliferation of recording and dissemination technologies for music will have to go beyond digital industries to consider new manufacturing techniques and standardized shipping that allow for cheap and easy outsourcing. They will have to consider the materials industries and changing politics of materials acquisition and disposal, which today shape the markets for musical instruments in countless ways. Ableton's new plastic controller for the company's widely used Live music-making software comes with a lengthy disquisition on proper disposal, alongside the other mandatory regulatory language in its manual. Meanwhile, speaker manufacturers, musicians, architects, and people involved in sound reinforcement have taken an unusually keen interest in the price of neodymium, a lightweight element that is replacing ceramic magnets in speakers, making them considerably lighter and more portable. Neodymium supply mainly comes from China, and price increases have affected the global market (a story that echoes the switchover during World War I from oil and wax to shellac finishes on disc records because of supply shortages). And those examples are drawn only from musical instruments industries. Imagine the construction of a city's new concert hall, opera house, or entertainment district as a media industries problem; or the materials inside of a smartphone; or the role of music education in musicians' and companies' online selfpromotion (and not only music companies per se: Energy beverage manufacturer Red Bull has been a major player in international electronic music culture). ${ }^{10}$

For scholars interested in music as a media industries issue, our first analytical step must be a simple subtraction. When we go looking for unity inside a music industry, we should instead assume a polymorphous set of relations among radically different industries and concerns, especially when we analyze economic activity around or through music. There is no "music industry." There are many industries with many relationships to music.

1 Jonathan Sterne teaches in the Department of Art History and Communication Studies and the History and Philosophy of Science Program at McGill University. He is author of MP3: The Meaning of a Format (Duke University Press, 2012); The Audible Past: Cultural Origins of Sound Reproduction (Duke University Press, 2003); and numerous articles on media, technologies, and the politics of culture. He is also editor of The Sound Studies Reader (Routledge, 2012). His new projects consider instruments and instrumentalities; histories of signal processing; and the intersections of disability, technology and perception. Visit his website at http://sterneworks.org. 
2 Pierre Bourdieu, Jean-Claude Chamboredon, and Jean-Claude Passeron, The Craft of Sociology: Epistemological Preliminaries, trans. Richard Nice (New York: Walter de Gruyter, 1991), 33-55.

3 Siva Vaidhyanathan, Copyrights and Copywrongs: The Rise of Intellectual Property and How It Threatens Creativity (New York: New York University Press, 2001); Kembrew McLeod, Freedom of Expression: Tales from the Dark Side of Intellectual Property Law (New York: Doubleday, 2005); Kembrew McLeod and Rudolf Kuenzli, eds., Cutting across Media: Appropriation Art, Interventionist Collage and Copyright Law (Durham: Duke University Press, 2011).

${ }^{4}$ LeRoi Jones(Amiri Baraka), Blues People: Negro Music in White America (New York: William Morrow and Company, 1963); Alan Merriam, The Anthropology of Music (Evanston: Northwestern University Press, 1964); Charles Keil and Steven Feld, Music Grooves (Chicago: University of Chicago Press, 1996); Christopher Small, Music-Society-Education (London: John Calder, 1977); Ivan Illich, Tools for Conviviality (New York: Harper and Row, 1973).

5 Christopher Small, Musicking: The Meanings of Performing and Listening (Hanover: Wesleyan University Press, 1998), 8.

6 Louise Meintjes, Sound of Africa! Making Music Zulu in a South African Studio (Durham: Duke University Press, 2003).

7 Paul Théberge, Any Sound You Can Imagine: Making Music/Consuming Technology (Hanover: Wesleyan University Press, 1997), 62.

8 On vintage instruments, see H. Stith Bennett, On Becoming a Rock Musician (Amherst: University of Massachusetts Press, 1980); Tom Wilder, ed., The Conservation, Restoration, and Repair of Stringed Instruments and Their Bows (Montreal: IPCI-Canada, 2010).

9 Jeremy Morris, "Sounds in the Cloud: Cloud Computing and the Digital Music Commodity," First Monday 16, no. 5 (2011); Jeremy Morris, "Making Music Behave: Metadata and the Digital Music Commodity," New Media and Society 14 , no. 5 (2012).

10 The environmental dimensions of media are especially important for media industries scholarship going forward. Not only do they offer a glimpse of a different valence of the "materiality" of media, a term now widely in fashion, this area is also a political front line for media reform. See Richard Maxwell and Toby Miller, Greening the Media (New York: Oxford University Press, 2012).

\section{Bibliography}

Bennett, H. Stith. On Becoming a Rock Musician. Amherst: University of Massachusetts Press, 1980.

Bourdieu, Pierre, Jean-Claude Chamboredon, and Jean-Claude Passeron. The Craft of Sociology: Epistemological Preliminaries. Translated by Richard Nice. New York: Walter de Gruyter, 1991.

Illich, Ivan. Tools for Conviviality. New York: Harper and Row, 1973. 
Jones, LeRoi (Amiri Baraka). Blues People: Negro Music in White America. New York: William Morrow and Company, 1963.

Keil, Charles, and Steven Feld. Music Grooves. Chicago: University of Chicago Press, 1996.

Maxwell, Richard, and Toby Miller. Greening the Media. New York: Oxford University Press, 2012.

McLeod, Kembrew. Freedom of Expression: Tales from the Dark Side of Intellectual Property Law. New York: Doubleday, 2005.

McLeod, Kembrew, and Rudolf Kuenzli, eds. Cutting across Media: Appropriation Art, Interventionist Collage and Copyright Law. Durham: Duke University Press, 2011.

Meintjes, Louise. Sound of Africa! Making Music Zulu in a South African Studio. Durham: Duke University Press, 2003.

Merriam, Alan. The Anthropology of Music. Evanston: Northwestern University Press, 1964.

Morris, Jeremy. "Making Music Behave: Metadata and the Digital Music Commodity."New Media and Society 14, no. 5 (2012): 850-66.

Morris, Jeremy. "Sounds in the Cloud: Cloud Computing and the Digital Music Commodity." First Monday 16, no. 5 (2011).

Small, Christopher. Music-Society-Education. London: John Calder, 1977.

Small, Christopher. Musicking: The Meanings of Performing and Listening. Hanover: Wesleyan University Press, 1998.

Théberge, Paul. Any Sound You Can Imagine: Making Music/Consuming Technology. Hanover: Wesleyan University Press, 1997.

Vaidhyanathan, Siva. Copyrights and Copywrongs: The Rise of Intellectual Property and How It Threatens Creativity. New York: New York University Press, 2001.

Wilder, Tom, ed. The Conservation, Restoration, and Repair of Stringed Instruments and Their Bows. Montreal: IPCI-Canada, 2010.

\section{(cc) BY-NC-ND}

Copyright (C) 2014 (Jonathan Sterne). Media Industries is and open-access, peer-reviewed, online academic journal. As such, we aim to participate in the open exchange of information. This work is licensed under a Creative Commons Attribution Noncommercial No Derivatives (by-nc-nd) License. Under this license, this work is available for sharing and noncommercial distribution provided the appropriate attribution is given. 